\title{
Unifying Mechanism for Nutrients as Anticancer Agents: Electron Transfer, Reactive Oxygen Species and Oxidative Stress
}

\author{
Peter Kovacic ${ }^{1} \&$ Ratnasamy Somanathan ${ }^{2}$ \\ ${ }^{1}$ Department of Chemistry and Biochemistry, San Diego State University, San Diego, CA 92182-1030, USA \\ ${ }^{2}$ Centro de Graduados e Investigación del Instituto Tecnológico de Tijuana, Apdo, Tijuana, B.C. Mexico \\ Correspondence: Ratnasamy Somanathan, Centro de Graduados e Investigación del Instituto Tecnológico de \\ Tijuana, Apdo. postal 1166, Tijuana, B.C. Mexico. E-mail: rsomanathan@mail.sdsu.edu
}

Received: March 13, 2017 Accepted: May 16, 2017 Online Published: May 29, 2017

doi:10.5539/gjhs.v9n8p66 URL: https://doi.org/10.5539/gjhs.v9n8p66

\begin{abstract}
A recent article deals with various nutrients in relation to bactericidal action. The present article focuses on a unifying mode of action for the nutrients, namely, resveratrol, epigallocatechin, polyene- $\beta$-carotene, polyene lycopene, piperine, curcumin, genistein, luteolin, sulforaphane and pomegranate extract. The mechanism is based on electron transfer, reactive oxygen species and oxidative stress, which comprises an extension of earlier reports involving agents. Most of the compounds are precursors of electron transfer quinones, whereas others fit into the polyene category. The nutrients are better known as antioxidants. The dichotomy is addressed.
\end{abstract}

Keywords: nutrients, cancer stem cells, anticancer, electron transfer, radicals, oxidative stress, reactive oxygen species
Abbreviations
ROS=Reactive oxygen species
OS= oxidative stress
$\mathrm{RNS}=$ reactive nitrogen species
$\mathrm{ET}=$ electron transfer

\section{Introduction}

Anticancer drugs are often synthetic agents originally derived from plants. Recently an article reported anticancer activity by diet nutrients, namely, resveratrol, epigallocatechin, polyene- $\beta$-carotene, polyene lycopene, piperine, curcumin, genistein, luteolin, sulforaphane and pomegranate extract (Scarpa \& Ninfali, 2015). Mode of action was attributed to cell signaling involving cancer stem cells. In 2007, a unifying mechanism for anticancer action was proposed as discussed below (Kovacic, 2007). The nutrients fit into the unifying mechanism which has been widely applied previously as set forth as follows (Kovacic \& Somanathan, 2010).

"The preponderance of bioactive substances, usually as the metabolites, incorporate ET functionalities. We believe these ET-metabolites play an important role in physiological responses. The main group include quinones (or phenolic precursors), metal complexes (or complexors), aromatic nitro compounds (or reduced hydroxylamine and nitroso derivatives), and conjugated imines (or iminium species). Resultant redox cycling is illustrated in Scheme 1. In vivo redox cycling with oxygen can occur, giving rise to oxidative stress (OS) through generation of reactive oxygen species (ROS), such as hydrogen peroxide, hydroperoxides, alkyl peroxides, and diverse radicals (hydroxyl, alkoxyl, hydroperoxyl, and superoxide) (Scheme 1). Cellular and mitochondrial enzymes can also perform catalytically in the reduction of $\mathrm{O}_{2}$. 


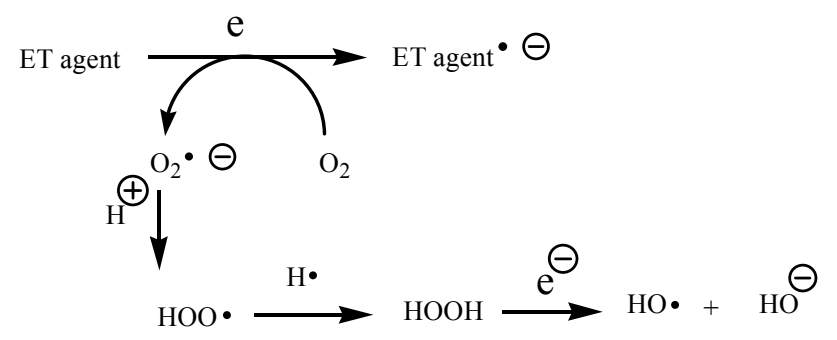

Scheme 1. Redox cycling with superoxide and ROS formation.

In some cases ET results in involvement with normal electrical effects (e.g., in respiration or neurochemistry). Generally, active entities possessing ET groups display reduction potentials in the physiologically responsive range, (i.e., more positive than about $-0.5 \mathrm{~V}$ ). Hence, ET in vivo can occur resulting in production of ROS which can be beneficial in cell signaling at low concentrations, but produce toxic results at high levels. Electron donors consist of phenols, $\mathrm{N}$-heterocycles or disulfides in proteins which produce relatively stable radical cations. ET, ROS and OS have been increasingly implicated in the mode of action of drugs and toxins, e.g., antiinfective agents (Kovacic \& Becvar, 2000), anticancer drugs (Kovacic \& Osuna, 2000), carcinogens (Kovacic \& Jacintho, 2001a), reproductive toxins (Kovacic \& Jacintho, 2001b), nephrotoxins (Kocavbic, Sacman, \& Wu-Weis, 2002), hepatotoxins (Poli, Cheeseman, Dianzani \& Slater, 1989), cardiovascular toxins (Kovacic \& Thurn, 2005), nerve toxins (Kovacic \& Somanathan, 2005), mitochondrial toxins (Kovacic, Pozos, Somanathan, Shangari, \& O'Brien, 2005), abused drugs (Kovacic \& Cooksy, 2005), pulmonary toxins (Kovacic \& Somanathan, 2009), ototoxins (Kovacic \& Somanathan, 2008) and various other categories (Halliwell \& Gutteridge, 1999).

There is a plethora of experimental evidence supporting the ET-ROS theoretical framework (Kovacic \& Becvar, 200 Kovacic \& Osuna, 2000; Kovacic \& Jacintho, 2001a; Kovacic \& Jacintho, 2001b; Kovacic, Sacman \& Wu-Weis, 2002; Poli, Cheeseman, Dianzani, \& Slater, 1989; Kovacic \& Thurn, 2005; Kovacic \& Somanathan, 2005; Kovacic, Pozos, Somanathan, Shangari, \& O’Brien, 2005; Kovacic \& Cooksy, 2005; Kovacic \& Somanathan, 2009; Kovacic \& Somanathan, 2008; Halliwell \& Gutteridge, 1999). This evidence includes generation of the common ROS, lipid peroxidation, degradation products of oxidation, depletion of AOs, effect of exogenous AOs, and DNA oxidation and cleavage products, as well as electrochemical data. This comprehensive, unifying mechanism is consistent with the frequent observation that many ET substances display a variety of activities (e.g., multiple-drug properties), as well as toxic effects.

It is important to recognize that mode of action in the bio domain is often involved with many physiological actions and is multifaceted. In addition to the ET-ROS-OS approach, other aspects may pertain, such as, enzyme inhibition, allosteric effects, receptor binding, metabolism and physical factors. A specific example involves protein binding by quinones in which protein and nucleophiles, such as amino or thiol, effect conjugate addition."

As indicated above, focus is on ROS-OS in relation to mechanism. However, most attention in the literature is paid to $\mathrm{AO}$ action in relation to physiological action, but is of little importance in the present case. An example is discussed with $\beta$-carotene.

\section{ROS and Cancer}

In recent years, a large body of literature has emerged documenting the link between ROS, reactive nitrogen species (RNS), OS and ET and cancer (Liou \& Storz, 2010; Sullivan \& Chandel, 2014; Haliwell, 2001).

Reactive oxygen species are radicals, ions or molecules that have unpaired electrons. They can be classified into two groups: free oxygen radicals and non-radical ROS (Table 1). Among these, superoxide, hydrogen peroxide and hydroxyl radicals are the most potent and well studied species. The roles of reactive oxygen species in tumorigenesis, prevention, and therapy has been discussed in more recent reviews (Liou \& Storz, 2010; Sullivan \& Chandel, 2014; Haliwell, 2001; Kovacic \& Jacintho, 2001a; Gupta, Hevia, Patchva, Park, Koh, \& Aggarwal, 2012). 
Table 1. Reactive oxygen and nitrogen species

\begin{tabular}{|lcll|}
\hline $\begin{array}{l}\text { Radical ROS } \\
\text { Superoxide }\end{array}$ & $\dot{\mathrm{O}_{2}-}$ & $\begin{array}{l}\text { Non-radical ROS } \\
\text { Hydrogen peroxide }\end{array}$ & $\mathrm{H}_{2} \mathrm{O}_{2}$ \\
Hydroxyl radical & $\mathrm{OH} \dot{ }$ & Singlet oxygen & $\mathrm{O}_{2}$ \\
Nitric oxide & $\mathrm{NHO}$ & Ozone & $\mathrm{O}_{3}$ \\
Organic radicals & $\mathrm{R}$ & Hypochlorous acid & $\mathrm{HOCl}$ \\
Peroxyl radicals & $\mathrm{ROOH}$ & Organic hydroperoxide & $\mathrm{ROOH}$ \\
Alkoxy radicals & $\mathrm{ROH}$ & Peroxynitrite & $\mathrm{ONOH}^{-}$ \\
Nitrogen dioxide & $\mathrm{NO}_{2}$ & Nitrous acid & $\mathrm{HNO}_{2}$ \\
\hline
\end{tabular}

A variety of enzymatic and non-enzymatic sources of ROS exists in the biological system. Enzymes within the cell are primary sources of ROS/RNS. Superoxide is produced by one electron reduction of oxygen by several enzymes, such as $\mathrm{NAD}(\mathrm{P}) \mathrm{H}$ oxidase, xanthine oxidase and cytochrome $\mathrm{P} 450$ within the cell. In addition to these, a number of external mediators also contribute to the ROS generation, such as ionizing radiation. Heavy metals, like $\mathrm{Hg}, \mathrm{Pb}$, $\mathrm{Cd}, \mathrm{Cr}$, and $\mathrm{Cu}$, metal complexes, nano particles, cigarette smoke, pollutants from automobiles, fossil burning furnaces, various drugs and certain types of other chemical compounds (Scheme 1) play a role. In cancer affected cells, high levels of ROS can result from mitochondrial dysfunction, high metabolic activity, cellular signaling, peroxisome activity, oncogene activity, oxidase activity, cyclooxygenase and lipoxigenase activity (Liou \& Storz, 2010; Sullivan \& Chandel, 2014; Haliwell, 2001).

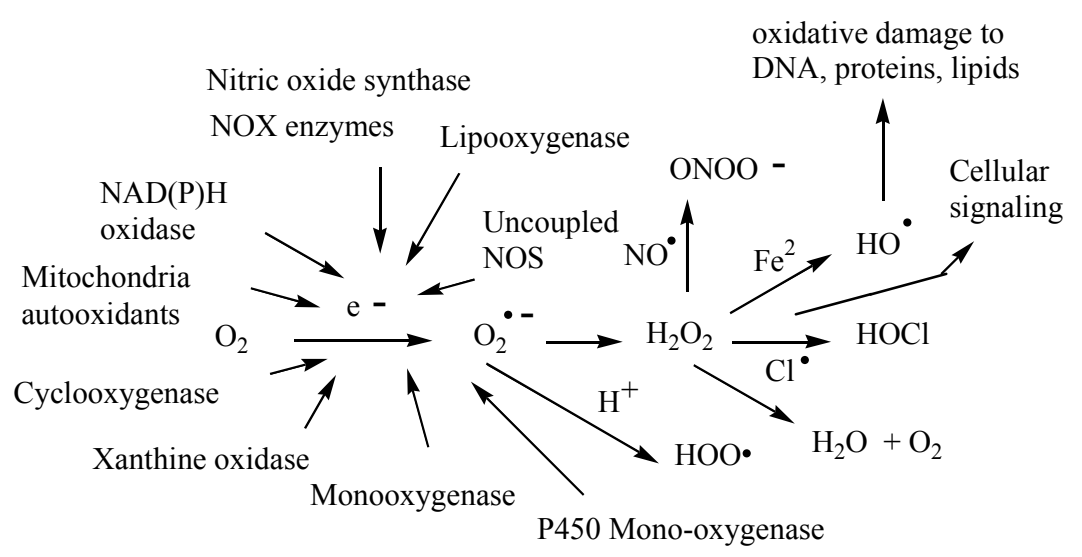

Scheme 1. Generation of ROS

In mitochondria, superoxide ROS is produced as a natural by-product of electron transport chain activity (Cui, Reichner, Mateo, \& Albino, 1994). The superoxide leaks through the mitochondrial permeability transition pore in the outer membrane into the cytoplasm, where it is dismutated into hydrogen peroxide by MnSOD or in the cytosol by $\mathrm{Cu} / \mathrm{ZnSOD}$. The diffusible hydrogen peroxide also serves as a second messenger, and may cross cellular membranes through members of the aquaporin family (Scarpoa \& Ninfali, 2015). Cancers arise from sites of chronic irritation, or inflammation and play a critical role in tumor progression (Liou \& Storz, 2010). Within the cancer cells, macrophages produce ROS which kill the tumor cells. This production of superoxide, hydroxyl radical, hydrogen peroxide, nitric oxide and peroxynitrite radicals contributes to tumor cell apoptosis (Liou \& Storz, 2010; Cui, Reichner, Mateo, \& Albino, 1994).

A 2012 review deals with ROS as initiators of cancer and also as therapy in destroying the cells (Cui, Reichner, Mateo, \& Albino, 1994). The review highlights: a) ROS play an important role in the initiation and progression of 
cancer; b) cancer cells exhibit greater ROS stress than normal cells, due to increased metabolic activity and mitochondrial dysfunction; c) cell-cycle progression is dependent on tyrosine kinase, which in turn depends on ROS; d) chronic inflammation due to cancer is mediated by ROS; e) ROS controls tumor expression genes, such as p53; and f) ROS can also suppress tumor growth. As a result of these accumulated data, a number of pro-oxidant and antioxidant based anticancer agents have been developed. Many of these approved drugs do show promise in suppressing cancer growth. However, a majority of the chemotherapeutic drugs shrink tumor size, but often fail to eradicate tumors.

\subsection{Cancer Stem Cells and Epithelial-Mesenchymal Transition Cells}

In the past decade, research has provided strong support for the theory of cancer stem cells (CSC) or tumor-initiating cells (TICs) involved in several human cancers (Aziz \& Wicha, 2013; Matchett \& Lappin; Enderling, 2015; Schukenburg, Blatt, Cerny-Reiterer, Sadovnik et al., 2014; Fulawka, Donizy, \& Halon, 2014; Kreso \& Dick, 2014; Oskarsson, Batlle, \& Massague, 2014; Lobo, Shimono, Qian, \& Clark, 2007). The hypothesis states that cancer cells arise in self-renewing cell populations and that the resulting cancers, like their normal organ counterparts, are composed of hierachially organized cell population (Aziz \& Wicha, 2013). Self renewing cancer cells maintain tumor growth and generate the diverse populations constituting the tumor bulk. Recently, epithelial-mesenchymal transition (EMT), a process that is reminiscent of that in cancer stem cells, along with ROS, has been associated with tumor metastasis, tumor cell migration, invasion and angiogenesis (Wang, $\mathrm{Li}, \&$ Sarkar, 2010; Diehn, Cho, Lobo, Kalisky et al., 2009). A current research focus is to develop therapy to suppress renewal of cancer stem cells by inhibiting the following signaling pathways, Hedgehog, Notch, Wnt, CXCR4, FOXM1, and miRNAs (Xia et al., 2012; Liu, Dontu, \& Wicha, 2005; Korkaya, Paulson, Charaf-Jauffret et al., 2009; Liu, Dontu, \& Mantle, 2006; Reya, Morrison, Clarke, \& Weissman, 2001; Dontu, Jacson, McNicholas, et al., 2004; Smally \& Dale, 1999; Clevers, 2006; Liu, Semenov, Han et al., 2002).

\subsection{Cancer Stem Cells and Natural Dietary Compounds}

The emergence of cancer stem theory has profound implications for cancer chemoprevention and therapy. Recently, studies have found that several dietary compounds can directly or indirectly affect cancer stem cells pathways $(\mathrm{Li}$, Wicha, Schwartz, \& Sun, 2011; Lee, Huang, \& Shyur, 2013; Khan, Adhami, \& Mukhtar, 2008). The dietary compounds, including resveratrol, epigallocatechin, polyene- $\beta$-carotene, polynene lycopene, piperine, curcumin, sulforaphane, soy isoflavone genistein, and vitamin D3, are known to effect directly or indirectly the self-renewable pathways (Li, Wicha, Schwartz, \& Sun, 2011). So far, several major pathways including Wnt/ $\beta$-catenin, Hedghog, and Notch have been identified as playing pivotal roles in CSC self renewal (Liu, Dontu, \& Mantle, 2006; Smally \& Dale, 1999; Dontu, Jackson, McNicholas et al., 2004).

\section{Curcumin}

Curcumin (diferuloylmethane) (Figure 1) is one of the active components of dietary spice tumeric (Curcuma longa. Linn) which is used in the preparation of curry, an East Indian dish. Curcumin possesses anti-inflammatory and antioxidant activities, and has been studied as a chemoprevention agent in several cancer models ( $\mathrm{Li}$, Wicha, Schwartz, \& Sun, 2011; Rahmani, Al Zohairy, Aly, \& Khan, 2014; Attari, Zahmatkesh, Aligholi et al., 2015; Gupta, Kismali, \& Agarwal, 2013) (Figure 1).<smiles>COc1cc(/C=C/C(=O)CC(=O)/C=C/c2ccc(O)c(OC)c2)ccc1O</smiles><smiles>COc1cc(/C=C/C2=COPC(/C=C/c3ccc(O)c(OC)c3)=C2)ccc1O</smiles>

Figure 1. Curcumin 
In relation to the unifying mechanistic approach, metabolism may yield a catechol type which lead to o-quinone or p-quinone structures, followed by ROS-OS (Kovacic \& Somanathan, 2015). Study reveals cucrcumin (Figure 1) induced caspase-3-mediated cleavage of $\beta$-catenin, leading to inactivation of $W n t / \beta$-catenin signaling in intestinal, gastric, and colon cancer cells (Park, Hahm, Park et al., 2005; Jaiswal, Marlow, Gupta, \& Narayan, 2002; Ramasamy, Ayob, Myint et al., 2015). Curcumin was also shown to attenuate the Wnt/ $\beta$-catenin pathway through down-regulation of the transcriptional coactivator p300 (Ryu, Cho, \& Song, 2008). A related study showed curcumin inhibits breast cancer stem cell migration by amplifying the E-cadherin/ $\beta$-catenin feedback loop (Mukherjee, Mazumdarm Chakraborty et al., 2014). Kakarala and coworkers showed curcumin inhibits Wnt signaling in breast cancer stem cell self renewal, but do not cause toxicity to differential cells (Kakaral, Brenner, Khorkaya et al., 2010). A similar study revealed curcumin has little toxicity against normal stem cells compared to cancer stem cells (Sordillo \& Helson, 2015). The phenol down regulates Notch-1 level with inhibition of cell growth and induction of apoptosis in pancreatic cancer cells (Wang, Zhang, Banerjee et al., 2006). Curcumin and epigallocatechin gallate combined specifically to inhibit STAT3 phosphorylation and STAT3-NFkB interaction was retained in breast cancer stem cells (Chung \& Vadgama, 2015). It has been demonstrated that curcumin can eliminate cancer stem cells in various human cancers (Yu, Kanwar, Patel et al., 2009; Lin, Liu, Li et al., 2011; Lim, Bisht, Bar et al., 2011). Yu and coworkers reported that the agent by itself or with other chemotherapeutics can prevent renewal of chemo resistant colon CSCs through the activation of STAT3 (signal transducer and activator of transcription) (Kovacic \& Somanathan, 2005; Kovacic, Pozos, Somanathan et al., 2005). A study by Lim and coworkers revealed that curcumin-nanoparticles can inhibit malignant brain tumor growth by controlling stem cell proliferation through STAT3 and Hedgehog pathway (Kovacic \& Cooksy, 2005).

\section{Genistein}

Genistein (Figure 2), an isoflavone, is the active ingredient in soya-rich food.

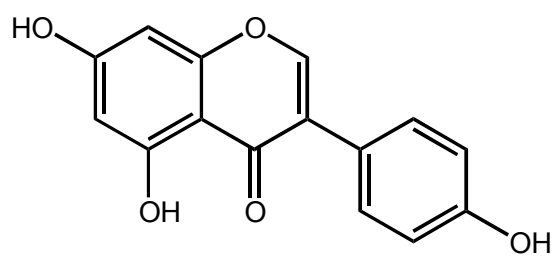

Figure 2. Genistein

Studies show that genistein and high soya-food consumption have been associated with reduced risk of breast and other forms of cancer among Asian Americans (Ziegler, Hoover, Pike et al., 1993; Iwasaki, Inoue, Otani et al., 2008; Verheus, Van Gils, Keinan-Boker et al., 2007; Barnes, 1995). Long term, low dose genistein consumption decreases stem cell population and sensitizes inflammatory breast cancer cell lines to radiation (Sims-Moutada, Opdenaker, Davis, \& Wu, 2015). A report deals with genistein as a dietary phytochemical target in human prostate cancer stem cells (Zhang, Li, Jiao et al., 2012). The phenol suppressed tumorsphere and colony formation of prostate cancer cells by inhibiting Hedgehog-Glil pathway. Genistein inhibited breast cancer cell growth, proliferation and promoted apoptosis (Fan, Fan, Wang et al., 2013). Genistein decreased breast cancer stem cells by inhibiting cancer stem cells by down regulating Hedgehog-Glil signaling pathway. Gli1 expression was inhibited, resulting in the attenuation of cancer stem like properties in gastric cancer cells (Yu, Shin, Lee et al., 2014). In addition, genistein suppresses the cell invasive capacity that is required for tumor growth and metastasis. A study showed inhibition by the phenol of $\beta$-catenin - mediated WNT signaling through gene expression by demethylating its silenced promoter in colon cancer cell lines (Zhang \& Chen, 2011). A similar study with renal cancer cells also showed inhibition of Wnt-signaling, thus effecting the proliferation and renewal of cancer stem cells (Hirata, Ueno, Nakajima et al., 2013). Data showed genistein, a natural chemo-preventive agent, inhibited cell growth, clonogenicity, cell migration and invasion, epithelial-mesemchymal transition, cancer stem cell phenotype, and formation of pancreatospheres in pancreatic cancer cells (Bao, Wang, Ali et al., 2011; Bao, Wang, Ali et al., 2011). A novel isoflavone NV-128, significantly targeted mitochondria to induce cell death in chemo-resistant ovarian cancer stem cells (Alvero, Montagna, Holmberg et al., 2011). The phenol protects hematopoietic stem cells against granulocyte colony-stimulating factor (G-CSF)-induced DNA damage (Souza, Silva, Calloway et al., 2014). There is ample precedent for metabolism entailing phenolic oxidation followed by conversion to catechol or hydroquinone type with subsequent oxidation to quinone followed by generation of ROS-OS. 


\section{Luteolin}

Luteolin, 3',4',5,7-tetrahydoxyflavone (Figure 3), is a common flavonoid that exists in many types of plants including fruits, vegetables, and medicinal herbs. Plants rich in luteolin have been used in Chinese traditional medicine for treating diseases, such as hypertension, inflammatory disorders, and cancer. Having multiple biological effects, the phenol functions as an antioxidant and as well as a pro-oxidant biochemically (Lin, Anxin Shi, Wang, \& Shen, 2008).<smiles>O=c1cc(-c2ccc(O)c(O)c2)oc2cc(O)cc(O)c12</smiles>

Figure 3. Luteolin

Two 2008 reviews deal with the luteolin's anticancer property with the induction of apoptosis, inhibition of cell proliferation, metastasis and angiogenesis (Lin, Anxin Shi, Wang \& Shen, 2008; Seelinger, Merfort et al., 2008). Furthermore, luteolin sensitizes cancer cells to therapeutic-induced cytotoxicity through suppressing cell survival pathways, such as phosphatidy linositol 3'-kinase/Akt, nuclear factor kappa B (NF-kB) (Yang, Cai, Yang et al., 2014), and X-linked inhibitor of apoptosis protein, and stimulating apoptosis pathways including those that induce the tumor suppressor p53. Data suggest luteolin could be an anticancer agent for various cancers (Scarpa \& Ninfali, 2015). Luteolin induced ROS acts as potential cytotoxic agent to human colorectal cell line (Pandurangan \& Ganapasam, 2013; Pandurangam, Sadagopan et al., 2013).

A study showed luteolin inhibits RNAs (RSK) and eradicates the CSC population (Davis, REipas, Hu et al., 2015). It effectively blocks progestin-dependent human breast cancer tumor growth and stem cell-like phenotype in human breast cancer (Cook, Liang, Besch-Williford et al., 2015). A similar study revealed retardation of growth by MCF-7 cells via inhibiting insulin growth factor (IGF-1) mediated P13K-Akt pathway dependent ERa in human breast cancer stem cells (Wang, Xie, Huo et al., 2012).

Luteolin inhibits the hypoxia-induced EMT in malignant melanoma cells both in vitro and in vivo via the regulation of $\beta 3$ integrin, suggesting action as a potential anticancer chemo preventive and chemotherapeutic agent (Ruan, Liu, Zhang et al., 2012). Luteolin induces apoptosis in multidrug resistant cancer cells via ROS generation, DNA damage, activation of p53, NF-kB signaling pathways, activation of p38 pathway and depletion of anti-apoptic proteins (Rao, Satelli, Moridani et al., 2011). Glioma is one of the most common malignant tumors affecting the central nervous system. Drug screening using curcurmin, luteolin, chrysin and apigenin, showed suppression of the tumor cells (Feng, Zhou, Liu, \& Tao, 2012).

\section{Sulforaphane}

Broccoli and broccoli sprouts contain large amounts of glucosinolates. Numerous studies have substantiated the chemopreventive properties of crucuferous vegetables against cancer, which has been attributed to the activity of various isothiocyanates that are enzymatically hydrolyzed from glucosinolates. Sulforaphane is formed from glucoraphanin, a major glucosinolate in broccoli/broccoli sprouts by enzymatic hydrolysis (Clarke, Dashwood \& Ho, 2008; Fahey, Zhang, \& Talalay 1997) (Scheme-3). A study revealed the naturally occurring $(R)$ - isomer is more effective than the synthetic $(S)$-isomer in a study of quinone reductase and glutathione $\mathrm{S}$-transferase activities (Scarpa \& Ninfali, 2015). Sulforaphane inhibits enzymes that convert procarcinogens to carcinogens, promote excretion of carcinogens, affect growth of transformed cells, induces apoptosis and cell cycle arrest ( $\mathrm{Li}$, Zhang, Korkaya et al., 2010). Accumulating evidence showed suforaphane inhibits breast cancer stem cells (Liu, Dontu, \& Wicha, 2005; Korkaya, Paulson, Charaf-Jauffret et al., 2009), and targets pancreatic tumor-initiating cells by NF-kB-induced antiapoptotic signaling (Kallifatidis, Rausch, Baumann et al., 2009). The compound was shown to target CSCs in different cancer through modulation of NF-kB, sonic hedgehog, epithelial-mesenchymal transition and Wnt/B-catenien pathways (Li \& Zhang, 2013). A related study showed targeting of sonic hedgehog signaling inhibition in pancreatic and prostate stem cell self-renewal (Rodova, Fu, Watkins et al., 2012; Kallifatidis, Labsch, Rausch et al., 2011). An investigation showed sulforaphane eliminated breast CSCs in vivo, by activation of 
caspase-3 (Li, Zhang, Korkaya et al., 2010; Park, Lim, Bae et al., 2007). A related study showed sulforaphane-induced apoptosis of human breast cancer cell involving PKC $\beta$-mediated S36 phosphorylation of $\mathrm{p} 66^{\text {she }}$ (Sako \& Singh, 2012). The isocyanate along with vitamin D shows greater down-regulation of the Wnt-signaling pathway (Lee, Yang, \& Liu, 2015). Sulforaphane and human tumor necrosis factor TNF-related apoptosis ligand (TRAIL) induce synergistic elimination of advanced prostate cancer-stem-like cells (Labsch, Bauer, Zhang et al., 2014). Mediated cleavage of Notch isoforms led to the inhibition of human prostate cancer cell migration (Hahm, Chandra-Kuntal, Desai et al., 2012). Data showed sulforaphane synergizes with quercetin to inhibit self-renewal capacity of pancreatic cancer stem cells by inhibiting the expression of Bcl-2 and XIAP, phosphorylation of FKFR, and activating caspase-3 (Srivastava, Tang, Zhu et. al. 2011).

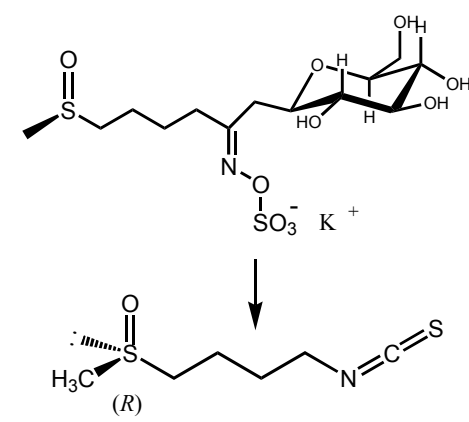

Scheme 3. Formation of sulforaphane from glucosinolate

\section{Pomegranate Extract}

Historically pomegranate (Punica granatum L), has been used as a medicine for variety of ailments in various cultures. In studies of human and murine models, pomegranate juice, peel, and oil have shown to possess anticancer activities, including interference with tumor cell proliferation, cell cycle, invasion, angiogenesis, anti-inflammatory, antiatherogenic, and antioxidant activities (Bhandari, 2012; Sudhakar, Venugopal, \& Karthikaeyan, 2015; Tuurini, Ferruzzi, \& Filmognari, 2015).

The peel of pomegranate possesses a higher content of polyphenols. The fruit contains large amounts of ellagic acid and its derivatives (Figure 4), along with punicalagin (Figure 6), a large polyphenol being the major constituent, possesses $>50 \%$ of the antioxidant activity of pomegranate juice. Pomegranate also ontains other polyphenols, such as anthocyanins, cyanidin (Figure 5), caffeic acid, coumaric acid and flavonols. Ellagic acid is metabolized by the colon microflora to form urolithins A and B that circulate in the blood stream reaching various organs, playing a role as antioxidants, anti-inflammatory and anticancerous agents (Sudhakar, Venugopal, \& Karthikaeyan, 2015). Four recent reviews deals with the role of pomegranate juice in breast cancer, colon cancer, pancreatic cancer, hepatocellular carcinoma, prostate cancer and human larynx epidermal carcinoma (Bhandari, 2012; Sudhakar, Venugopal \& Karthikaeyan, 2015; Tuurini, Ferruzzi, \& Filmognari, 2015). Mechanistically, as discussed in prior sections, the catechol can act as o-quinone precursusor leading to ET-ROS-OS as part of the unifying theme.<smiles></smiles>

(a)<smiles>O=C(O)c1cc(O)c(O)c(O)c1-c1c(C(=O)O)cc(O)c(O)c1O</smiles>

(b)

Figure 4. Ellagic acid (a) and hydrolysis product (b) 


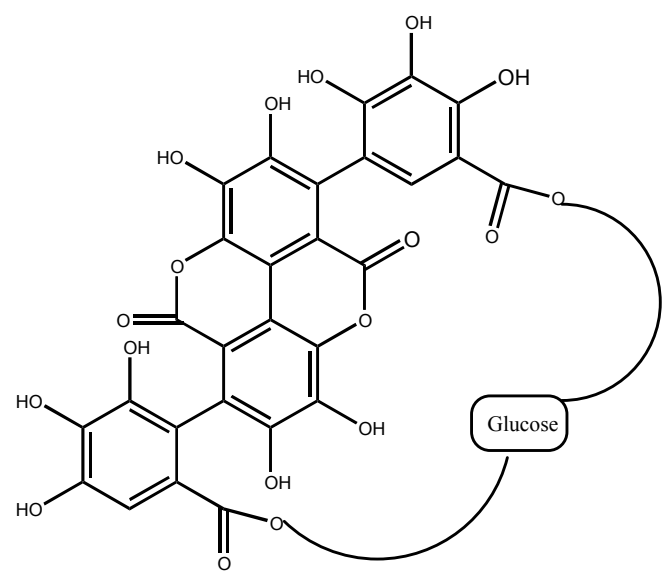

Figure 5. Punicalgin<smiles>Oc1cc(O)c2cc(O[GaH2])c(-c3ccc(O)c(O)c3)[o+]c2c1</smiles>

cynanidin-3-glucoside<smiles>O=c1oc2cc(O)ccc2c2ccc(O)cc12</smiles>

Urolithin<smiles>O=C(O)/C=C/c1ccc(O)c(O)c1</smiles>

Caffeic acid

Figure 6. Polyphenols

\section{Resveratrol (RSV)}

There is considerable literature that documents RSV (Figure 7) as a pro-oxidant, which is in accord with the unifying theme of ET-ROS-OS (Kovacic \& Somanathan, 2010). Compounds related to RSV display oxidative properties (Miura, Muraoka, \& Fujimoto, 2002). Conditions are important for DNA oxidation leading to apoptosis (Athar, Back, Kopelovich et al., 2009). A study revealed formation of superoxide (Ahmad, Clement, \& Pervaiz, 2003). In the dark, AO properties prevail whereas under light exposure, oxidative effects are predominant (Gadacha, ben-Attia, Bonnfont et al., 2009). Another rationale exists for the pro-oxidant effects based on complex formation with heavier metals capable of ET (see Introduction). This route is more favorable for catechol types.

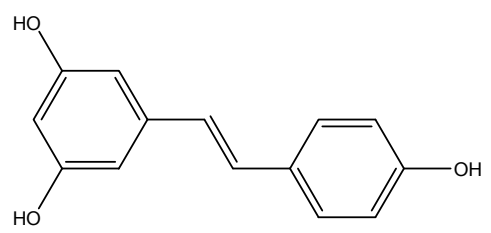

Figure 7. Resveratrol

Relevant research literature has been published in the last five years. RSV is similar to chemotherapeutic drugs in relation to DNA damage (Colin, Limagne, Ragot et al., 2014). The insult was the result of large scale generation of ROS. The results are rationalized in the Introduction involving oxidation of RSV to a catechol type followed by oxidative conversion to an o-quinone leading to ET and ROS-OS. 
Exposure to RSV and histone deactylase inhibitors resulted in prolonged ROS generation with subsequent DNA cleavage (Yasen, Chen, Hock et al., 2012). A free radical scavenger hindered production of ROS, DNA damage and apoptosis, indicating an important role for oxidative insult.

RSV together with UVA produces pronounced OS in mitochondria which leads to apoptosis in keratinocytes (Yar, Menevse, Dogan et al., 2012). These findings may have practical application in treatment of skin cancer. The polyphenol is known to act as an antitumor agent and in chemoprevention (Stocco, Toledo, Salvador et al., 2012). High concentrations were needed to induce death of cancer cells. Exposure to RSV resulted in apoptosis and DNA damage in human gastric cancer cells via ROS (Wang, Li, Meng, \& Jia, 2012). Exposure of the cells to SOD or catalase countered apoptosis by destroying ROS. In a report on colorectal cancer, RSV interacted with mitochondria resulting in enhancement of ROS and lipid peroxidation (Zhou, Chen, Yang et al., 2014). Combination of RSV with 5-flurouracil resulted in enhanced OS. Arsenic trioxide is a powerful anticancer drug for treatment of leukemia (Gu, Chen, Jiang, \& Zhang, 2015). The combination of RSV and arsenite increased apoptotic cancer cell death through generation of OS. A report deals with OS in eye cells of diabetic rats involving an increase in OS (Boyer, Jandova, Janda et al., 2012). Protein carbonyl content was increased and GSH levels were decreased. We suggest a result of ROS-OS.

A study was made of a related derivative, 3,3',4,4'-tetrahydoxy-trans-stilbene (Mikula-Pietrasik, Sosinka et al., 2015). In cancer cells, drug treatment resulted in increased generation of ROS and catalase. Cytotoxicity was related to enhanced apoptosis. There also was formation of 8-OH-2'-dG resulting from DNA oxidation. Higher hydroxylated analogs of RSV display both pro-oxidant and AO effects (Kucinska, Piotrowska, Luczak et al., 2014). Pro-oxidant activity is attributed to cytotoxicity and apoptotic effects. Cell death occurred along with OS and decrease in GSH and SOD (Santandreu, Valle, Oliver, \& Roca, 2011). Cytotoxicity may be related to generation of pro-oxidative metabolites. The following phenolic derivatives of trans-stilbene were involved: 3,3', 4,4'-tetrahydroxy, 3,4,4',5-tetrahydroxy and 3,3',4,4', 5,5'-hexahydroxy. These phenols can act as precursors of quinones which enter into ET-ROS-OS (see Introduction).

\section{Epigallocatechin gallate (EGCG)}

EGCG (Fig.8) is a polyphenol prevalent in green tea (Scarpa \& Ninfali, 2015). Clinical trials comprise the phenol alone or together with platinum $(\mathrm{Pt})$ drugs involving synergism against prostate and colon cancers. One mode of action entails induction of apoptosis in tumor cells and animal models, which can result from OS (Halliwell \& Gutteridge, 1999). Increase in ROS occurs during gallate-induced apoptosis of hepatic cancer cells ( $\mathrm{Li}, \mathrm{Nie}, \mathrm{Yu}, \&$ Xie, 2009). The compound enhanced the production of radicals, both ROS and RNS (Jeong, Park, Cho et al., 2015). A study was made of the drug effect on Leishmania (Inacio, Gervazoni, Canto-Cavalheiro et al., 2014). Results suggest a mode of action involving ROS. The effect was reversed by catalase, providing evidence for ROS involvement.

In relation to the ET-ROS-OS unifying mechanism, the catechol portion can act as precursor of an o-quinone which is an ET agent capable of inducing ROS-OS which plays a role in cancer destruction.

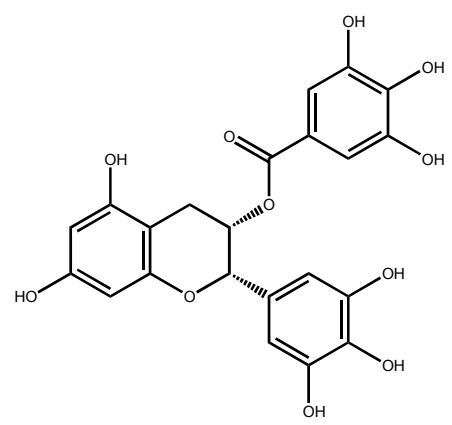

Figure 8. Epigallocatechin gallate

\section{Piperine}

Piperine (Figure 9) is an alkaloid which produces the pungency of pepper. Various mechanisms have been advanced in connection with bioactivity. The compound activates ions associated with pain-sensing nerve cells (McNamara, Randall, \& Gunthorpe, 2005), and also inhibits enzymes involved with metabolism of xenobiotics (Bhardwaj, Glaser, Becquemont et al., 2002; Srinivasan, 2007), of drugs (Atal, Dubey, \& Singh, 1985; Reen, Jamwal \& Taneja, 1993) and of glucuronidation (Singh, Dubey, \& Ata, 1986). A molecular mechanism is proposed for killing of breast cancer stem cells involving inhibition of Wnt signaling (Kakaral, Brenner, Khakaya et al., 
2010). Evidence revealed increased generation of ROS in piperine-treated cancer cells (Yaffe, Doucette, Walsh, \& Hoskin, 2013; Moorthy \& Kathiresan, 2013). The AO N-acetylcysteine decreased apoptosis in the treated cells, demonstrating that the induced cytotoxicity was mediated by ROS, at least in part.

The unifying mechanism of ET-ROS-OS can also be applied by two methods. In one case, the polyene benzenoid structure in conjugation with amide may participate in ET. In the other instance, the catechol ether portion undergoes oxidative dealkylation to form a substituted catechol with subsequent oxidation to ET o-quinone.

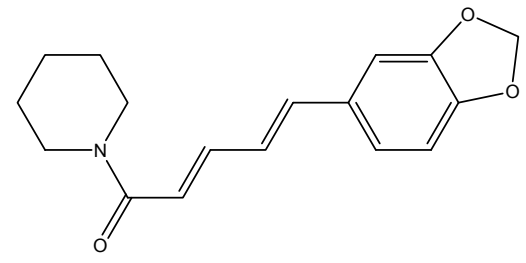

Figure 9. Piperine

\section{Polyene-Lycopene}

Lycopene (Figure 10), possessing a red color, is found in tomatoes, watermelon and pink grapefruit (Scarpa \& Ninfali, 2015). Research demonstrates that vegetables with high amounts of the polyene decrease various cancers, such as prostate, cervic and digestive systems (Dow, 2005). A mixture of the compound with selenium and vitamin E inhibits prostate cancers with increase in survival. Growth of lung cancer cells is suppressed. Lycopene from tomatoes may act against prostate cancer, although the evidence is not conclusive (Choi \& Lee, 2015). Also, mitochondrial dysfunction occurred. A similar report deals with action as a bacteriacide involving the hydroxyl radical which damages E.coli DNA. Cell filamentation also took place (W. Lee \& D. G. Lee, 2014).

There are numerous reports of AO action displayed by lycopene with several examples provided herein. A study indicated possible alleviation of OS (Chen, Song, \& Zhang, 2013). Administration of the polyene provided protection from mitochondrial dysfunction and OS (Snadhir, Mehrotra, \& Kamboj, 2010). The compound is a powerful radical scavenger and its AO properties are involved in many health effects (Kujawska, Ewertowska, Adamska et al., 2014). A tomato paste suppressed OS in rats. Lycopene pretreatment suppressed ROS generation and increased survival (Kim, Han, Lee et al., 2015).

A 2006 book provides rationale for the ability of certain compounds to act as both pro- and anti- oxidants (Kovacic \& Somanathan, 2006).

Relevant information concerning mechanism is relation to amphotericin B is presented in the section on $\beta$-carotene.

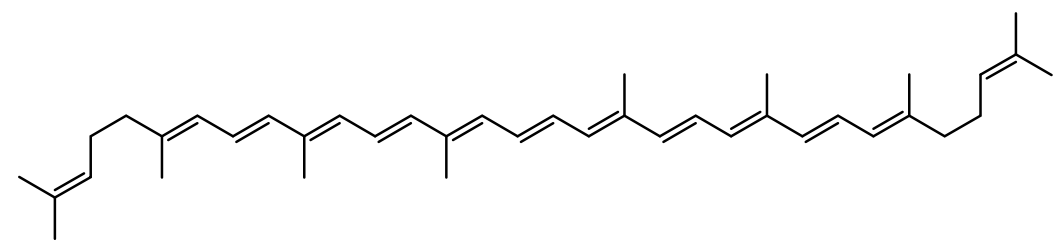

Figure 10. Lycopene

\section{Polyene- $\beta$-Carotene}

$\beta$-Carotene (Figure 11) (Scarpa \& Ninfali, 2015). An orange-red pigment, occurs in carrots, pumpkins and sweet potatoes. The polyene reduces the risk of breast cancer in women before menopause. $\beta$-Carotene was found to exacerbate UV carcinogenesis in mice (Black \& Gerguis, 2003). A mode of action was suggested for the repair of the $\beta$-carotene radical cation, a potent oxidizing entity formed by reaction with oxidizing species.

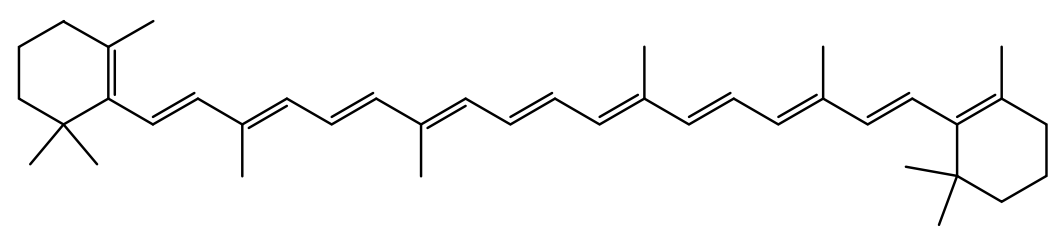

Figure 11. B-Carotene 
Useful information is provided by electron affinity (EA) studies on amphotericin B (Figure 12) (Kovacic \& Cooksy, 2012). The EAs are found to be 1.30 and $1.36 \mathrm{eV}$ for the conformers. These values are considerably higher than those prominent ET functionalities, such as quinones $(0.54-0.64 \mathrm{eV})$ and aromatic nitro compounds $(0.59 \mathrm{eV}$ for dinitrophenol). The EA values should be more favorable for lycopene having eleven conjugates and $\beta$-carotene with nine versus seven for amphotericin B.

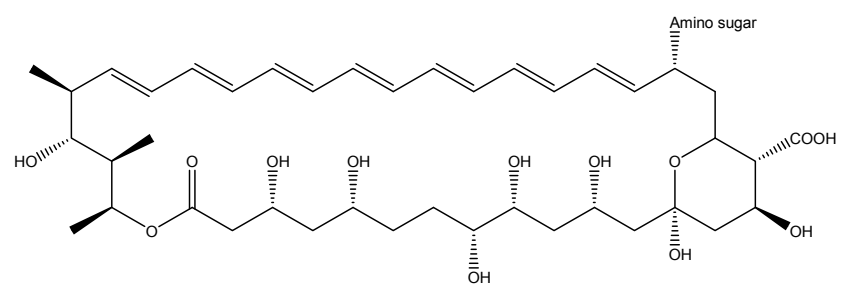

Figure 12. Amphotericin B

\section{Conclusion}

Nutrients display various beneficial and harmful effects with focus on anticancer action. The ET-ROS-OS scheme serves as unifying mechanism. Polyenes and ET quinone metabolites appear to play roles as ET agents. Evidence indicates involvement of nutrients as AOs in some actions. The unifying mode of action adds to prior studies.

\section{Acknowledgements}

Editorial support by Thelma Chavez is acknowledged, as well as topic suggestion by Darlene Nowack and literature search by Linda Muroi.

\section{Competing Interests Statement}

The authors declare that they have no competing or potential conflicts of interest regarding the publication of this paper.

\section{References}

Ahmad, K. A., Clement, M. V., \& Pervaiz, S. (2003). Pro-oxidant activity of low doses of resveratrol inhibits hydrogen peroxide-induced apoptosis. Ann. NY. Acad. Sci., 1010, 365-373. https://doi.org/10.1196/annals.1299.067

Atal, C. K., Dubey, R. K., \& Singh, J. (1985). Biochemical basis of enhanced drug bioavailability by piperine: evidence that piperine is a potent inhibitor of drug metabolism. J. Pharmacol. Exp. Ther., 232, 258-262. PMID: 3917507.

Athar, K. A., Back, J. H., Kopelovich, L., Bickers, D. R., \& Kim, A. L. (2009). Multiple molecular targets of resveratrol: anti-carcinogenic mechanism. Arch. Biochem. Biophy., 486, 95-102. https://doi.org/10.1016/j.abb.2009.01.018 PMID: 19524131.

Alvero, A. B., Montagna, M. K., Holmberg, J. C., Craveiro, V., Brown, D., \& Mor, G. (2011). Targeting the mitochondria activates two independent cell death pathways in the ovarian cancer stem cells. Mol. Cancer Ther., 10, 1385-1393. https://doi.org/ 10.1158/1535-7163 MCT-11-0023.

Attari, F., Zahmatkesh, M., Aligholi, H., Mehr, S. E., Sharifzadeh, M., Gorji, A., ... Hassanzadeh, G. (2015). Curcumin as a double-edged sword for stem cells: dose, time and cell type-specific response to curcumin. $J$. Pharamceut. Sci., 23, 33. http://doi.org/10.1186/s40199-015-0115-8

Aziz, E., \& Wicha, M. S. (2013). Cancer stem cells-the evidence accumulates. Clin. Chem., 59, 205-207. https://doi.org/10.1373/clinchem.2012.195990

Bao, B., Wang, Z., Ali, S., Kong, D., Banerjee, S., Ahamed, A., ... Sarkar, F. H. (2011). Metformin inhibits cell proliferation, migration and invasion by attenuating CSC function mediated by deregulating miRNAs in pancreatic cancer cells. Cancer Prevention Res., 307, 26-36. https://doi.org/10.1158/1940-6207 CAPR-11-0299.

Bao, B., Wang, Z., Ali, S., Kong, D., Banerjee, S., Ahamed, A., ... Sarkar, F. H. (2011). Over-expression of FoxM1 leads to epithelial-mesenchymal transition and cancer stem cell phenotype in pancreatic cancer cells. J. Cell Biochem., 112, 2296-2306. https://doi.org/10.1002/jcb.23150

Barnes, S. (1995). Effect of genistein on in vitro and in vivo models of cancer. J. Nutr., 125, 777S-783S.

Bhandari, P. R. (2012). Pomegranate (Punica granatum L). Ancient seeds for modern cure: review of potential therapeutic applications. Int. J. Nutr. Pharamacol. Neurol. Dis., 2, 171-184. 
https://doi.org/10.4107/0972-124x.138678

Bhardwaj, R. K., Glaser, H., Becquemont, L., Klotz, U., Gupta, S. K., \& Fromm, M. F. (2002). Piperine, a major constituent of black pepper, inhibits human P-glycoprotein and CYP3A4. J. Pharmacol. Exp. Ther., 302, 646-650.https://doi.org/10.1124/jpet.102.03472

Black, H. S., \& Gerguis, J. (2003). Modulation of dietary vitamins E and C fails to ameliorate $\beta$-carotene exacerbation of UV carcinogenesis in mice. Nutr. Cancer, 45, 36-45. https://doi.org/10.3109/03630269.2010.485873

Boyer, J. Z., Jandova, J., Janda, J., Vleugels, F. R., Elliott, D. A., \& Sligh, J. E. (2012). Resveratrol-sensitized UVA induced apoptosis in human keratinocytes through mitochondrial oxidative stress and pore opening. $J$. Photochem. Phoobiol. B., 113, 42-50. https://doi.10.1016/j.jphotobiol.2012.04.013

Chen, J., Song, Y., \& Zhang, L. (2013). Effect of lycopene supplementation on oxidative stress: an exploratory systematic review and meta-analysis of randomized controlled trials. J. Med. Food, 16, 361-374. https://doi.org/10.1089/jmf.2012.2682

Choi, H., \& Lee, D. G. (2015). Lycopene induces apoptosis in Candida albicans therough reactive oxygen species and mitochondrial dysfunction. Biochmie, 115, 108-115. https://doi.org/10.1016/j.biochi.2015.05.009

Chung, S. S., \& Vadgama, J. V. (2015). Curcumin and epihallcatechin gallate inhibit the cancer stem cell phenotype via down-regulation of STAT3-NFkB signaling. Anticancer Res. 35, 39-46. PMCID: PMC4290892.

Clarke, J. D., Dashwood, R. H., \& Ho, E.(2008). Multi-targeted prevention of cancer by sulforaphane. Cancer Lett., 269, 291-304. https://doi.org/10.1016/j.canlet.2008.04.018

Clevers, H. (2006). Wnt/ $\beta$-catenin signaling in development and disease. Cell, 127, 469-480.http://doi.org/10.1016/j.cell.200610.018

Colin, D. J., Limagne, E., Ragot, K., Lizard, G., Ghiringhelli, F., Solary, E., ... DElmas, D. (2014).The role of reactive oxygen species and subsequent DNA damage response in the emergence of resistance towards resveratrol in colon cancer models. Cell Death Dis., 5, E1533. https://doi.org/10.1038.CDDIS.2014.486

Cook, M. T., Liang, Y., Besch-Williford, C., Goyette, S., Mafuvadze, B., \& Hyder, S. M. (2015). Luteolin inhibits progestin-dependent angiogenesis, stem cell like chracteristics, and growth of human breast cancer xenografts. Springerplus, 4, 444. https:// doi.org/10.1186/s40064-015-1242-x

Cui, S., J. S. Reichner, R. B. Mateo., J. E., \& Albino. (1994). Activated murine macrophages induce apoptosis in tumor cells through nitric oxide dependent or -independent mechanism. Cancer Res., 54, 2462-2467. PMID:8162595.

Davis, A. H., Reipas, K., Hu, K., Berns, R., Firmino, N., Stratford, A. L., Dunn, S. E. (2015). Inhibition of RSK with the novel small-molecule inhibitors LJI308 overcomes chemoresistance by eliminating stem cells. Oncotarget, 6, 10570. https://doi.org/10.18632/oncotarget.4135

Diehn, M., Cho, R. W., Lobo, N. A., Kalisky, T., Dorie, M. J., Kulp, A. N., ... Clarke, M. F. (2009). Association of reactive oxygen species levels and radioresistance in cancer stem cells. Nature, 458, 780-783. https://doi.org/ 10.1038/nature07783

Dontu, G., Jackson, K. W., McNicholas, E., Kawamura, M. J., Abdallah, W. M., \& Wicha, M. S. (2004). Role of Notch signaling in cell-fate determination of human mammary stem/progenitor cells. Breast Cancer Res., 6 , R605-615. https://doi.org/10.11861bcr920

Dow, F. K. (2005). Qualified health claims: letter regarding tomatoes and prostate cancer (lycopene health claim coalition) (Docket No. 2004Q-0201) U.S. Food and Drug Administration.

Enderling, H. (2015). Cancer stem cells: small subpopulation or evolving fraction? Integr. Biol., 7, 14-23. https://doi.org/10.1039/C4IB00191E

Fahey, J. W., Zhang, Y., \& Talalay, P. (1997). Broccoli sprouts: an exceptionally rich source of inducers of enzymes that protect against chemical carcinogens. Proc. Natl. Acad. Sci., 94, 10367-10372

Fan, P., Fan, S., Wang, H., Mao, J., Shi, J., Ibrahim, M. M., ... Li, L. (2013). Genistein decreases the breast cancer stem-like cell population through Hedgehog pathway. Stem Cell Res. Theapy., 4, 146. https://doi.org/10.1186/scrt357

Feng, X., Zhou, Q., Liu, C., \& Tao, M-L. (2012). Drug screening study using glioma stem-like cells. Mol. Med. Rep., 6, 1117-1120. https://doi.org/10.3892/mmr.2012.1040 
Fulawka, L., Donizy, P., \& Halon, A. (2014). Cancer stem cells-the current status of an old concept: literature review and clinical approaches. Biol. Res., 47, 66. https://doi.org/10.1186/0717-6287-47-66

Gadacha, W., ben-Attia, M., Bonnfont-Rousseelot, D., Aouani, E., Ghanem-Boughanmi, N., \& Touitou, Y. (2009). Resveratrol opposite effects on rat tissue lipid peroxidation: pro-oxidant during day-time and antioxidant at night. Free Rad. Res., 14, 154-158. https:// doi.org/10.1179/135100009x466131

Gu, S., Chen, C., Jiang, X., \& Zhang, Z. (2015). Resveratrol synergistically triggers apoptotic cell death with arsenic trioxide via oxidative stress in human lung adenocarcinoma A549 cells. Biol. Trace Elem. Res., 163, 112-123. https://doi.org/ 10.1007/s12011-014-0186-2

Gupta, S. C., Hevia, D., Patchva, S., Park, B., Koh, W., \& Aggarwal, B. B. (2012). Upsides and downsides of reactive oxygen species for cancer: the roles of reactive oxygen species in tumorigenesis, prevention and therapy. Antiox. Redox Sig., 16, 1295-1322. https://doi.org/10.1089/ars.2011.4414

Gupta, S. C., Kismali, G., \& Aggarwal, B. A. (2013). Curcumin, a componenet of tumeric : from farm to pharmacy. BioFactors, 39, 2-13. https://doi.org/10.1002/biof.1079

Hahm, E-R., Chandra-Kuntal, K., Desai, S., \& Singh, S. V. (2012). Notch activation is dispensable for D, L-sulforaphane-mediated inhibition of human prostate cancer cell migration. PLoS ONE, 7, e44957. https://doi.org/10.1371/journal.pone.0044957

Halliwell, B. (2001). Free radical and other reactive species in disease. Encyclopedia of Life Science, 1-7.

Halliwell, B., \& Gutteridge, J. M. C. (1999). Free Radicals in Biology and Medicine; Oxford University Press, New York.

Hirata, H., Ueno, K., Nakajima, K., Tabatabai, Z. L., Hinoda, Y., \& Dahiya, R. (2013). Genistein downegulates onco-miR-12606 and inhibits Wnt-signaling in renal cancer cells. Bri. J. Cancer, 108, 2070-1078. https://doi.org/10.1038/bjc.2013.173

Inacio, J. D. F., Gervazoni, L., Canto-Cavalheiro, M. M., \& Almeida-Amaral, E. E. (2014). The effect of (-)-epigallocatechin-3-O-gallate in vitro and in vivo in Meishmania braziliensis: Involvement of reactive oxygen species as a mechanism of action. PLoS One, e3093. https://doi.org/10.1371/journal.pntd.0003093

Iwasaki, M., Inoue, M., Otani, T., Susazuki, S., Kurahashi, N., Miura, T., Yamamoto, S., \& Tsugane, S. (2008). Plasma isoflavone level and subsequent risk of breast cancer among Japanese women: a nested case-control study from Japan. Public Health Center-based prospectice study group. J. Clin. Oncol., 26, 1677-1683. https://doi.org/10.1200/jco.2007.13.9964

Jaiswal, A. S., Marlow, B. P., Gupta, N., \& Narayan, S. (2002). Beta-catenin-mediated transactivation and cell-cell adhesion pathways are important in curcumin (diferuylmethane)-induced growth arrest and apoptosis in colon cancer cells. Oncogene, 21, 8414-8427. https://doi.org/10.1038/sj.onc.1205947

Jeong. J. Y., Park, M. N., Cho, E. S., Jang, H-J., \& Lee, H-J. (2015). Epigallocatechin-3-gallate-induced free-radical production upon adipogenic differentiation in bovine bone-marrow mesenchymal stem cells. Cell Tiss. Res., 362, 87-92. https://doi.org/ 10.1007/s0044-015-2191-y

Khan, N., Adhami, V. M., \& Mukhtar, H. (2008). Apoptosis by dietary agents for prevention and treatment of cancer. Biochem. Pharmacol. 76, 1333-1339. https;//doi.org/10.1016/j.bcp.2008.07.015

Kakaral, M., Brenner, D. E., Khorkaya, H., Cheng, C., Tazi, K., Ginestier, C., ... Wicha, M. S. (2010). Targeting breast cancer stem cells with cancer preventive curcumin and piperine. Breast Cancer Res. Treat., 122, 777-785. https://doi.org/10.1007/s10549-009-0612-х

Kallifatidis, F., Rausch, V., Baumann, B., Apel, A., Beckermann, B. M., Groth, A., ... Herr, I. (2009). Sulforaphane targets pancreatic tumor-initiating-cells by NF-kB-induced antiapoptotic signaling. Gut, 58, 949-963. https://doi.org/10.1136/gut.2008.149039

Kallifatidis, G., Labsch, S., Rausch, V., Mattern, J., Gladkich, J.; Moldenhauer, G.; Büchler, M. W., Salnikov, A., \& Herr, I. (2011). Sulforaphane increases drug-mediated cytotoxicity toward cancer stem-like cells of pancrease and prostate. Mol. Ther., 19, 188-195. https://doi.org/10.1038/mt.2010.216

Kim, J. Y., Han, J. H., Lee, J. H., Bae, I., Yoon, Y. M., Kwon,, S. M., \& Lee, S. H. (2015). Pretreatment with lycopene attenuates oxidative stress-induced apoptosis in human mesenchymal stem cells. Bimol. Ther. (Seoul,), 23, 517-524. https://doi.org/ 10.4062/biomolther.2015.085

Korkaya, H., Paulson, A., Charaf-Jauffret, E., Ginestier, C., Brown, M.; Dutcher, J.; Clouthier, G., \& Wicha, M. S. (2009). Regulation of mammary stem/progenitor cells by PTEN/Akt/ß-catenin signaling. PloS Biol., 7, 
e1000121. https://doi.org/ 10.137/journal.pbio.1000121

Kovacic. P. (2007). Unifying mechanism for anticancer agents involving electron transfer and oxidative stress: clinical implications. Med. Hypotheses, 69, 510-516. https://doi.org/ 10.1016/j.mehy.2006.08.046

Kovacic, P., \& Becvar, L. E. (2000). Mode of action of anti-infective agents: focus on oxidative stress and electron transfer. Curr. Pharmaceut. Des., 6, 277-309. https://doi.org/10.2174/1381612003401046

Kovacic, P., \& Cooksy, A. L. (2005). Unifying mechanism for toxicity and addiction of abused drugs, electron transfer and reactive oxygen species. Med. Hypotheses, 64, 357-367. https://doi.org/10.1016/j.mehy.2004.07.021

Kovacic, P., \& Cooksy, A. (2012). Novel, unifying mechanism for amphotericin B and other polyene drugs: electron affinity, radical, electron transfer, autoxidation, toxicity, and antifungal action. Med. Chem. Comm., 3, 274-280. https://doi.org/10.1039/c2MD002.67A

Kovacic, P., \& Jacintho, J. D. (2001). Mechanism of carcinogenesis. Focus on oxidative stress and electron transfer. Curr. Med. Chem., 8, 773-796. https://doi.org/10.2174/0929867013373084

Kovacic, P., \& Jacintho, J. D. (2001a). Reproductive toxins. Pervasive theme of oxidative stress and electron transfer. Curr. Med. Chem., 8, 863-892. https://doi.org/ 10.2174/0929867013372878

Kovacic, P., \& Jacintho, J. D. (2001b). Mechanisms of carcinogenesis: focus on oxidative stress and electron transfer. Curr. Med. Chem., 8, 773-796.https://doi.org/ 10.2174/0929867013373084

Kovacic, P., \& Osuna, J. A. (2000). Mechanism of anti-cancer agents: Focus on oxidative stress and electron transfer. Curr. Pharmaceut. Des., 6, 143-167. https://doi.org/ 10.2174/1381612810006020143

Kovacic, P.; Sacman, A., \& Wu-Weis, M. (2002). Nephrotoxins: Widespread role of oxidative stress and electron transfer. Curr. Med. Chem., 9, 823-847. https://doi.org/ 10.2174/09298670460683

Kovacic, P., \& Somanathan, R. (2010). Mechanism of conjugated imine and iminium species, including marine alkaloids: electron transfer, reactive oxygen species, therapeutics and toxicity. Curr. Bioact. Compds., 6, 46-59. https://doi.org/ 10.2174/157340710790711782

Kovacic, P., Pozos, R. S., Somanathan, R., Shangari, R., \& O’Brien, P. J. (2005). Mechanism of mitochondrial upcouplers, inhibitors, and toxins: Focus on electron transfer, free radicals, and structure-activity relationships. Curr. Med. Chem., 5, 22601-2623. PMID: 16248817. https://doi.org/10.2174/092986705774370646

Kovacic, P., \& Somanathan, R. (2005). Neurotoxicity: The broad framework of electron transfer, oxidative stress and protection by antioxidants. Curr. Med. Chem-CNS Agents., 5, 249-258.https://doi.org/10.2174/156801505774913044

Kovacic, P., \& Somanathan, R. (2009). Pulmonary toxicity and environmental contamination: radicals, electron transfer and protection by antioxidants. In: Rev. Environ. Contam. Toxicol. Whitacre, D. E. (Ed); Springer, New York, 201, 41-69. https://doi.org/ 10.1016/j.mehy.2007.06.045

Kovacic, P., \& Somanathan, R. (2008). Ototoxicity and noise trauma: Electron transfer, reactive oxygen species, cell signaling, electrical effects, and protection by antioxidants: Practical medical aspects. Med. Hypotheses, 70, 914-923. https://doi.org/ 10.1016/j.mehy.2007.06.045

Kovacic, P., Somanathan, R., \& Abadjian, M-C. Z. (2015). Natural monophenols as therapeutics, antioxidants and toxins: electron transfer, radicals and oxidative stress. Nat. Prod. J., 5, 142-151.https://doi.org/10.2174/221031550503151016153837

Kovacic, P., \& Somanathan, R. (2010). Multifaceted approach to resveratrol bioactivity. Oxid. Med. Cell Longev, 3, 86-100. https://doi.org/10.461/oxim.3.2.11147

Kovacic. P., \& Somanathan, R. (2006). Beneficial effects of antioxidants in relation to carcinogens, toxins and various illnesses, In Frontiers in Antioxidants Research, Panglosi, H. V. (ed.) Nova Science, Ch. 1, 1-38.

Kovacic, P., \& Thurn, L. A. (2005). Cardiovascular toxicity from the perspective of oxidative stress, electron transfer, and prevention by antioxidants. Curr. Vasc. Pharmacol., 3, 107-117. https://doi.org/10.2174/1570161053586912

Kreso, A., \& Dick, J. E. (2014). Evolution of the cancer stem cell model. Cell Stem Cell, 14, $275-$. https://doi.org/10.1016/j.stem.2014.02.006

Kucinska, M., Piotrowska, H., Luczak, M. W., Mikula-Pietrasik, J., Ksiazek, K., Wozniak, M., ... Murias, M. (2014). Effects of hydroxylated reseveratrol analogs on oxidative stress and cancer cells death in human acute 
T cell cancer cell lines: prooxidative potential of hydroxylated analogs. Chem. Biol. Interact., 209, 96-110. https://doi.org/10.1016/j.cb.2013.12.009

Kujawska, M., Ewertowska, M., Adamska, T., Sadowski, C., Ignatowicz, E., \& Jodynis-Liebert, J. (2014). Antioxidant effect of lycopene-enriched tomato paste on N-nitrosodiethylamine-induced oxidative stress in rats. J. Physiol. Biochem., 70, 981-990. https://doi.org/10.1007/s13105-014-0367-7

Labsch, S., Bauer, N., Zhang, Y., Aleksandrowicz, E.; Gladkich, J., Schönsuegel, F., \& Herr, I. (2014). Sulforaphane and TRAIL induce a synergistic elimination of advanced prostate cancer stem like cells. Int. J. Oncol., 44, 1470-1480. https://doi.org/ 10.3892/ijo.2014.2335

Lee, W-L., Huang, J-Y., \& Shyur, L-F. (2013). Phytoagents for cancer management: regulation of nucleic acid oxidation, ROS, and related mechanisms. Oxid. Med. Cell. Long. https://doi.org/10.1155/2013/925804

Lee, B. H., Yang, Y., \& Liu, Z. (2015). Synergistic mediation of sulforaphane and vitamin- D on the Wnt-signaling pathway. J. Nature Sci.1, e36. www.jnsci.org/content/36.

Lee, W., \& Lee, D. G. (2014). Lycopene-induced hydroxyl radical causes oxidative DNA damage in Escherichia coli. J. Microbiol. Biotechnol., 24, 1232-1237. https://doi. org/10.4014/jmb.1406.06009

Li, Y., Wicha, M. S., Schwartz, S. J., \& Sun, D. (2011). Implications of cancer stem cell theory for cancer chemoprevention by natural dietary compounds. $J$. Nutr. Biochem., 22, 799-806. https://doi.org/10.1016/j.nutbio.2010.11.001

Li, Y., Zhang, T., Korkaya, H., Liu, S., Lee, H-F., Newman, B., ... Sun, D. (2010). Sulforaphane, a dietary component of broccoli/broccoli sprouts, inhibits breast cancer stem cells. Clin. Cancer Res., 16, 2580-2590. https://doi.org/10.1158/1078-0432.CCR-09-2937

Li, Y., \& Zhang, T. (2013).Targeting cancer stem cells with sulforaphane, a dietrary componenet from broccoli and broccoli sprouts. Future Oncol., 9, 1097-1103. https://doi.org/10.221/fon.13.108

Li, W., Nie, S., Yu, Q., \& Xie, M. (2009). (-)-Epigallocatechin-3-gallate induces apoptosis of human hepatoma cells by mitocondrial pathways related to reactive oxygen species. J. Agric. Food Chem., 57, 6685-6691. https://doi.org/10.1021/jf901396f

Lim, K. J., Bisht, S., Bar, E. E., Maitra, A., \& Eberhart, C. G. (2011). A polymeric nanoparticle formulation of curcumin inhibits growth, cologenicity and stem-like fractions in malignant brain tumors. Cancer Biol Ther. 11, 464-473. https://doi.org/ 10.416/cbt.11.5.14410

Lin, L.,Liu, H., Li, H., Li, P. K., Fuchs, J., Shibata, H., Iwabuchi, Y., \& Lin, J. (2011).Targeting colon cancer stem cells using a new curcumin analogue, GO-Y030. Br. J. Cancer, 105, 212-220. https://doi.org/10.1038/bjc.2011.200

Lin, Y., Anxin Shi, R., Wang, X., \& Shen, H-M. (2008). Luteolin, a flavonoid with potentials for cancer prevention and therapy. Curr. Cancer Drug Targets, 8, 634-646.

Liou, G-Y., \& Storz, P. (2010). Raective oxygen species in cancer. Free Rad. Res., 44, https://doi.org/10.3109/10715761003667554

Liu, S.; Dontu, G., \& Wicha, M. S. (2005).Mammary stem cells, self-renewal pathways, and carcinogenesis. Breast Cancer Res. 7, 86-95. https://doi.org/10.1186/bcr1021

Liu, S., Dontu G., \& Mantle, I. D. (2006). Hedgehog signaling and Bmi-1 regulate self-renewal of normal and malignant human mammary stem cells. Cancer Res., 66, 6063-6071. https://doi.org/10.1158/0008-5472.CAN-06-0054

Liu, C., Semenov., Han, C., Baeg, G. H., Tan, Y., Zhang, Z., Lin, X., \& He, X. M. (2002). Control of $\beta$-catenin phosphorylation/degradation by dual-kinase mechanism. Cell, 108, 837-847. https://doi.org/10.1016/S0092-8674(02)00685-2

Lobo, N. A., Shimono, Y., Qian, D., \& Clarke, M. F. (2007). The biology of cancer stem cells. Annu. Rev. Cell Dev. Biol., 23, 675 699. https://doi.org/10.1146/annurev.cellbio.22.010305.104154

McNamara, F. N., Randall, A., \& Gunthorpe, M. J. (2005). Effects of piperine, the pungent componenet of black pepper, at the human vanilloid receptor (TRPV1). Br. J. Pharmacol., 144, 781-790. https://doi.org/10.1038/sj.bip.0706040

Matchett, K. B., \& Lappin, T. R. (2014). Concise reviews: cancer stem cells: from concept to cure. Stem Cells, 32, 2563-2570. https://doi.org/10.1002/stem, 1798

Mikuła-Pietrasik, J., Sosińska, P., Murias, M., Wierzchowski, M., Brewińska-Olchowik, M., Piwocka, K., ... 
Ksiazek, K. (2015). High potency of a novel 3,3',4,4'-tetrahydroxy-trans-stilbene, against ovarian cancer is associated with oxidative -stress- mediated inbalance between DNA-damage accumulation and repair. Cell Longev. 2015:135691. https://doi.org/10.1155/2015/135691

Miura, T., Muraoka, S., \& Fujimoto, Y. (2002). Inactivation of cerine kinase induced by stilbene derivatives. Pharmacol. Toxicol. 90, 66-72. PMID: 12071428.

Moorthi, C., \& Kathiresan, K. (2013).Curcumin-piperine/curcumin-quercetin/curcumin-silibinin dual drug-loaded nanoparticulate combination therapy: a noval approach to target and treat multidrug-resistant cancers. $J$. Med. Hypotheses Ideas, 7, 15-20. https://doi.org/1016/j.jmhi.2012.10.005204

Mukherjee, S., Mazumdar, M., Chakraborty, S., Manna, A., Saha, S., Khan, P., ... Das, T. (2014). Curcumin inhibits breast cancer stem cell migration by amplifying the E-cadherin/ $\beta$-catenin negative feedback loop. Stem Cell Res., 5, 116. https://doi.org/10.1186/scrt506

O’Connor, M. L., Xiang, D., Shigdar, S., Macdonald, J., Li, Y., Wang, T., ... Duan, W. (2014). Cancer stem cells: A contentious hypothesis now moving forward. Cancer Lett., 344, 180-187. https://doi.org/10.1016/j.canlet.2013.11.012

Oskarsson, T., Batlle, E., \& Massague, J. (2014). Metastatic stem cells: sounces, niches and vital pathways. Cell Stem Cell, 306. https://doi.org/10.1016/j.stem.2014.02.002

Pandurangan, A. K., Sadagopan, S. K. A., Dharmalingam, P., \& Ganapasam, S. (2013). Luteolin, a bioflavonoid, attenutaes azoxymethane-induced effects of mitochondrial enzymes in Balb/c mice. Asian Pacific J. Cancer Prev., 14, 6669-6672. https://doi.org/10.7314/APJCP.2014.15.16.6669

Pandurangan, A. K., \& Ganapasam, S. (2013). Cytotoxic effect of luteolin on human colorectal cancer cell line (HCTR-15): crucial involvement of reactive oxygen species. Middle East J. Cancer, 4, 175-180.

Park, C. H., Hahm, E. R., Park, S., Kim, H. K., \& Yang, C. H. (2005). The inhibitory mechanism of curcumin and its derivative against beta-catenin/Tcf signaling. FEBS Lett., 579, 2965-2971. https://doi.org/10.1016/j.febslet.2015.04.013

Park, S. Y., Lim, G. Y., Bae, S. J., Yoo, Y. H., \& Choi, Y. H. (2007). Induction of apoptosis by isothiocyanate sulforaphane in human cervical carcinoma HeLa and hepatocarcinoma HepG2 cells through activation of caspase 3. Oncol. Rep., 18, 181-187. https://doi.org/ 10.3892/or.18.1.181

Poli, G., Cheeseman, K. H., Dianzani, M. U., \& Slater, T. F. (1989). Free Radicals in the Pathogenesis of Liver Injury, Pergamon, New York, 1989, pp.1-330. PMid:2468677

Rahmani, A. H., Al Zohairy, M. A., Aly, S. M., \& Khan, M. A. (2014). Curcumin: a potential candidate in prevention of cancer via modulation of molecular pathways. BioMed. Res. Int. https://doi.org/a0.1155/2014/761608

Ramasamy, T. S., Ayob, A. Z., Myint, H. H. L., Thiagarajah, S., \& Amini, F. (2015).Targeting colorectal cancer stem cells using curcumin and curcumin analogues: insights into the mechanism of the therapeutic efficacy. Cancer Cell Int. 15, 96. https://doi.org/10.1186/s12935-015-0241-x

Rao, P. S., Satelli, A., Moridani, M., Jenkins, M., \& Rao, S. (2011). Luteolin induces apoptosis in multidrug resistant cancer cells without affecting the drug transporter function: involvement of cell line-specific apoptotic mechanism. Int. J. Cancer, 130, 2703-2714. https://doi.org/10.1002/ijc.26308

Reen, C. K., Jamwal, D. S., \& Taneja, S. C. (1993). Impairment of UDP-glucose dehydrogenase and glucuronidation activities in liver and small intestine of rat and guinea pig in vitro by piperine. Biochem. Pharmacol. 46, 229-238. PMID: 8347144.

Reya, T., Morrison, S. J., Clarke, M. F., \& Weissman, I. L. (2001). Stem cells, cancer, and cancer stem cells. Nature, 414, 105-111. https://doi.org/10.1038/35102167

Ruan, J-S.’ Liu, Y-P.; Zhang, L. , Yan, L-G., Fan, F-T., Shen, C-S., ... Lu, Y. (2012). Luteolin reduces the invasive potential of malignant melonama cells by targeting $\beta 3$ integrin and the epithelia-mesenchymal transition. Acta Pharmacol. Sinica, 33, 1325-1331. https://doi.org/10.1038/aps.2012.93

Rodova, M., Fu, J., Watkins, D. N., Srivatava, R. K., \& Shanker, S. (2012). Sonic hedgehog signaling inhibition provides opportunities for targeted therapy by sulforaphane in regulating pancreatic cancer stem cell self-renewal. Plos One, 7, e46083. https://doi.org/ 10.137/journal.pone,0046083

Ryu, M. J., Cho, M., \& Song, J. Y. (2008). Natural derivatives of curcumin attenuate the Wnt/beta-catenin pathway through down-regulation of the transcriptional coactivator p300. Biochem. Biophys. Res. Commun., 377, 
1304-1308. https://doi.org/10.1016/j.bbrc.2008.10.171

Sako, K., \& Singh, S. V. D, (2012). L-Sulforphane-induced apoptosis in human breast cancer cells by the adapter protein p66 ${ }^{\text {she }} J$. Cellular Biochem., 113, 599-610. https://doi.org/10.1002/jcb.23386

Santandreu, F. M., Valle, A., Oliver, J., \& Roca, P. (2011). Resveratrol potentiates the cytotoxic oxidative stress induced by chemotherapy in human cáncer cells. Cell Physiol. Biochem., 28, 219-228. https://doi.org/10.1159/000331733

Seelinger, G., Merfort, I., Wölfle, U., \& Schempp, C. (2008). Anti-cancer effects of the flavonoid luteolin. Molecules, 13, 2628-2651. https://doi.org/10.339/molecules13102628.

Sullivan, L. B., \& Chandel, N. S. (2014). Mitochondrial reactive oxygen species and cancer. Cancer Metab. 2, 17. https://doi.org/10.1186/2049-3002-2-17

Schukenburg, A., Blatt, K., Cerny-Reiterer, S., Sadovnik, I., Hermann, H., Marian, B., ... Valent, P. (2015). Cancer stem cells in basic science and in translational oncology: can we translate into clinical application? J. Hematol. Oncol. 8, 16, https://doi.org:10.1186/s13045-015-0113-9

Smally, M. J., \& Dale, T. C. (1999). Wnt signaling in mammalian development and cancer. Cancer Metastasis Rev., 18, 215-230. https://doi.org/10.1023/A:1006369223282

Scarpa, E-S., \& Ninfali, P. (2015). Phytochemicals as innovative therapeutic tools against cancer stem cells. Int. J. Mol. Sci., 16, 15727-15742. https://doi.org/ 10.339/ijms160715727

Sims-Mourtada, J., Opdenaker, L. M., Davis, J., \& Wu, C. (2015). Long term, low dosage genistein decreases stem cell population and sensitizes inflammatory breast cancer cell lines to radiation. Cancer Stud. Mol. Open J., 2, 60-65. https://doi.org/10.17140/csmmoj-2-107

Singh, J., Dubey, R. K., \& Ata, C. K. (1986). Piperine-mediated inhibition of glucuronidation activity in isolated epithelial cells of the guinea-pig small intestine: evidence that piperine lowers the endogenous UDP-glucuronic acid content. Pharmacol. Exp. Ther., 236, 488-493. PMID: 3080587.

Snadhir, R., Mehrotra, A., \& Kamboj, S. S. (2010). Lycopene prevents 3-nitropropionic acid-induced mitiochondrial oxidative stress and dysfunctions in nervous system. Neurochem Int., 57, 579-587. https://doi.org/10.1016/j.neuint.2010.07.005

Sordillo, P. P., \& Helson, L. (2015). Curcumin and cancer stem cells: curcumin has asymmetric effects on cancer and normal stem cells. Anticancer Res., 35, 599-614.

Souza, L. R., Silva, E., Calloway, E., Kucuk, O., Rossi, M., \& McLemore, M. L. (2014). Genistein protects hematopoietic stem cells against G-CSF-induced DNA damage. Cancer Prev. Res., 7, 534-544. https://doi.org/10.1158/1940-6207.CAPR-13-0295

Srinivasan, K. (2007). Black pepper and its pungent principal-piperine. A review of diverse physiological effects. Crit. Rev. Food Nutr., 47, 735-748. https://doi.org/ 10.1080/10408390601062054

Srivastava, R. K., Tang, S-N., Zhu, W., Meeker, D., \& Shanker, S. (2011). Sulforphane synergizes with quercetin to inhibit self-renewal capacity of pancreatic cancer stem cells. Front. Biosci., 3, 515-528. https:// doi.org/10.2741/266

Stocco, B., Toledo, K., Salvador, M., Paulo, M., Koyama, N., \& Torqueti, Toloi, M. R. (2012). Dose-dependent effect of resveratrol on bladder cancerc cells: chemoprevention and oxidative stress. Maturitas, 72, 72-78. https://doi.org/ 10.1016/j.maturitas.2012.02.004

Sudhakar, S., Venugopal, V. D., \& Karthikaeyan, S. (2015). Antioxidant and anticancer activity of the pomegranate and their role in cancer prevention and therapy. Int. J. Life Sci. Res., 3, 77-84. ISSN 2348-3148

Tuurini, E., Ferruzzi, L., \& Filmognari, C. (2015). Potential effects of pomegranate polyphenols in cancer prevention and therapy. Oxid. Med. Cellul. Long. https://doi.org/10.1155'2015/938475

Verheus, M., Van Gils, C. H., Keinan-Boker, L., Grcae, P. B.; Bingham, S. A., \& Peeters, P. H. (2007). Plasma phytoestrogens and subsequent breast cancer risk. J. Clin. Oncol., 25, 648-655. https://doi.org/10.1200/jco.2006.06.0244

Wang, Z., Zhang, Y., Banerjee, S.; Li, Y., \& Sarkar, F. H. (2006). Notch-1 down-regulation by curcumin is associated with the inhibition of cell growth and induction of apoptosis in pancreatic cancer cells. Cancer, 106, 2503-2508. https://doi.org/10.1002/cncr.21904

Wang, Z., Li, Y., \& Sarkar, F. H. (2010). Signaling mechanism(s) of reactive oxygen species in epithelial-mesenchymal transition reminiscent of cancer stem cells in tumor progression. Curr. Stem Cell Res. 
Ther. 5, 74-80. https://doi.org/10.2174/157488810790442813

Wang, Z., Li, W., Meng, X., \& Jia, B. (2012). Resveratrol induces gastric cancer cell apopotosis via reactive oxygen species, but independent of sirtuin1. Clin. Exp. Pharmacol. Physiol., 39, 227-232. https://doi.org/10.1111/j.1440.1681.2016.05660.x

Wang, L-M., Xie, K-P., Huo, H-N., Shang, F.; Zou, W., \& Xie, M-J. (2012). Luteolin inhibits proliferation induced by IGF-1 pathway dependent ER $\alpha$ in human breast cancer MCF-7 cells. Asian Pacific J. Cancer Prev., 13, 1431-1437. https://doi.org/10.7314/APJCP.2012.13.4.1431

Xia, J., Chen, C., Chen, Z., Miele, L., Sarkar, F. H., \& Wang, Z. (2012). Targeting pancreatic cancer stem cells for cancer therapy. Biochem. Biophysica Acta., 1826, 385-399. https://doi.org/10.1016/j.bbcan.2012.06.002

Yaffe, P. B., Doucette, C. D., Walsh, M., \& Hoskin, D. W. (2013). Piperine impairs cell cycle progression and causes reactive oxygen species-dependent apoptosis in rectal cancer cells. Exp. Mol. Pathol., 94, 109-114. https://doi.org/10.1016/j.yexm.2012.10.008

Yang, Y., Cai, X., Yang, J., Sun, X., Hu, C., Yan, Z., ... Cao, P. (2014). Chemoprevention of dietary digitoflavone on colitis-associated colon tumorigenesis through inducing Nrf2 signaling pathway and inhibition of inflammation. Mol. Cancer, 13, 48. https://doi.org/10.1186/1476-4598-13-48

Yaseen, A., Chen, S., Hock, S., Rosato, R., Dent, P., Dai, Y., \& Grant, S. (2012). Resveratrol sensitizes acute myelogenous leukemia cells to histone deactylase inhibitors through reactive oxygen species mediated activation of the extrinsic apoptotic pathway. Mol. Pharmacol., 82, 1030-1041. https://doi.org/10.1124/mol.112.079624

Yar, A. S., Menevse, S., Dogan, I., Alp, E., Ergin, V., Cumaoglu, A., Aricioglu, A., Ekmekci, A., \& Menevse, A. (2012). Investigation of ocular neovascularization related genes and oxidative stress in diabetic rat eye tissues after resveratrol treatment. J. Med. Food, 15, 391-398.https://doi.org/10.1089/jmf.2011.0135

Yu, Y., Kanwar, S. S.,Patel, B. B., Nautiyal, J., Sarkar, A. P., \& Majumdar, A. P. (2009). Elimination of colon cancer stem-like cells by combination of curcumin and FOLFOX. Transl. Oncol., 2, 321-3287. PMID: 19956394.

Yu, D., Shin, H-S., Lee, Y. S., Lee, D., Kim, S., \& Lee, Y. C. (2014). Genistein attenuates cancer stem cell characteristics in gastric cancer through the downregulation of Gli1. Oncol. Rep., 31, 673-678. https://doi.org/10.3892/or.2013.2893

Zhang, Y., \& Chen, H. (2011). Genistein attenuates WNT signaling by up-regulating SFRP2 in human colon cancer cell line. Exp. Biol. Med. (Maywood), 236, 6714-6722.

Zhang, L., Li, L., Jiao, M., Wu, D., Wu, K., Li, X., Z. ... He, D. (2012). Genistein inhibits the stemness properties of prostate cancer cells through Hedgehog-Gli1 pathway. Cancer Lett., 323, 48-57. https://doi.org/10.1016/j.canlet.2012.03.037

Ziegler, R. G., Hoover, R. N., Pike, M. C., Hildesheim, A., Nomura, A. M., West, D. W., ... Horn-Ross, P. L. (1993). Migration patterns and breast cancer risk in Asian-American women. J. Natl. Cancer Inst., 85, 1819-1827. https://doi.org/10.1093/jnci/85.22.1819

Zhou, X., Chen, M., Yang, J., Deng, H., Yi, L., \& Mi, M-t. (2014). Resveratrol regulates mitochondrial reactive oxygen species homeostasis through Sirt3 signaling pathway in human vascular endothelial cells. Cell Death Dis., 5, e1576. https://doi.org/10.1038/cddis.2014.530

\section{Copyrights}

Copyright for this article is retained by the author(s), with first publication rights granted to the journal.

This is an open-access article distributed under the terms and conditions of the Creative Commons Attribution license (http://creativecommons.org/licenses/by/4.0/). 